\title{
Effects of Detritus on the Mosquito Culex pipiens: Phragmites and Schedonorus (Festuca) Invasion Affect Population Performance
}

\author{
Paul T. Leisnham ${ }^{1, *}$, Brandon Scott ${ }^{1}$, Andrew H. Baldwin ${ }^{1} \mathbb{D}$ and Shannon L. LaDeau ${ }^{2}$ \\ 1 Department of Environmental Science and Technology, University of Maryland, College Park, MD 20742, \\ USA; branscott33@gmail.com (B.S.); baldwin@umd.edu (A.H.B.) \\ 2 Cary Institute of Ecosystem Studies, Millbrook, NY 12545, USA; ladeaus@caryinstitute.org \\ * Correspondence: leisnham@umd.edu; Tel.: +1-301-405-8569
}

Received: 2 October 2019; Accepted: 23 October 2019; Published: 25 October 2019

check for updates

\begin{abstract}
Species interactions that influence the performance of the exotic mosquito Culex pipiens can have important effects on the transmission risk of West Nile virus (WNV). Invasive plants that alter the vegetation communities of ephemeral ground pools may facilitate or resist the spread of C. pipiens (L.) by altering allochthonous inputs of detritus in those pools. To test this hypothesis, we combined field surveys of roadside stormwater ditches with a laboratory microcosm experiment to examine relationships between C. pipiens performance and water quality in systems containing detritus from invasive Phragmites australis (Cav.) Trin. Ex Steud., introduced Schedonorus arundinaceus (Schreb.) Dumort., or native Juncus effusus L. or Typha latifolia L. In ditches, C. pipiens abundance was unrelated to detritus species but female $C$. pipiens were significantly larger from ditches with $S$. arundinaceus and smaller with J. effusus. Larger and smaller C. pipiens were also produced in microcosms provisioned with S. arundinaceus and J. effusus, respectively, yet the per capita rate of population of change did not vary. Larger females from habitats with S. arundinaceus were likely caused by faster decay rates of S. arundinaceus and resultant increases in microbial food, but lower survival as a result of fouling and higher tannin-lignin concentrations resulted in little changes to overall population performance. Larger female mosquitoes have been shown to have greater potential for transmitting arboviruses. Our findings suggest that changed community-level interactions from plant invasions in urban ephemeral ground pools can affect the fitness of $C$. pipiens and possibly increase WNV risk.
\end{abstract}

Keywords: Culex pipiens; Festuca; Juncus; Phragmites; stormwater; Typha; West Nile

\section{Introduction}

As the coexistence of exotic species becomes more common, understanding how their interactions affect the success and impacts of biological invasions is increasingly important. Interactions among exotic species' can be divided into two general categories based on how they affect invasion success. Exotic species can have facilitative effects on one another, broadly proposed as the invasion meltdown hypothesis (IMH), whereby positive interactions amongst invasive species lead to positive population-level feedback that intensifies the impacts of invasive species or facilitates secondary invasions [1]. Alternatively, exotic species can have inhibitory effects on other exotics that are already established in or are newly colonizing a system, by decreasing niche opportunities [2], altering the physical environment and nutrient fluxes, or impacting food webs [3].

Mosquitoes that use small ephemeral water bodies, such as stormwater structures (e.g., catch basins, ditches) or containers (e.g., tree holes, trash) for their developmental stages (eggs and larvae), provide excellent model systems to investigate the effects of interactions between exotic species on invasions. 
Small ephemeral habitats typically have low photosynthetic activity from plankton and algae, and the predominant resource for mosquito larvae consists of allochthonous detritus (mostly plant material) and associated microbes [4]. Density dependent competition is common in these habitats and can strongly negatively affect the production of adults [5-9]. Different species of detritus support different quantities (and possibly different species) of microbial food for mosquito larvae, which reduces resource competition and improves mosquito performance [10-13]. For example, larvae raised with animal detritus (e.g., dead insects) have higher survival and faster development than larvae raised with plant detritus [14-17]. Likewise, larvae raised with rapidly decaying plant detritus have similarly better larval performance than larvae raised with slow-decaying plant detritus [14-17]. In turn, differences in larval performance as a result of detritus type have been related to adult body size $[13,14,18]$ and survival $[17,19]$, while variation in available larval food resources more generally have also been related to fecundity [20-22], biting rate [23], and susceptibility to viral infection [24-26], all of which are expected to affect disease transmission at the individual and population scales [27-32]. Although resource competition is often the dominant ecological process regulating mosquito populations in ephemeral habitats, populations may also be regulated by abiotic factors, including litter-based toxins. Rapidly decaying plant detritus can increase toxicity from secondary metabolites, such as phenolics, lignin, and tannins $[33,34]$, or due to microbial blooms that coat the water surface and prevent the larvae from breathing [11].

Invasive plants in ephemeral habitats have the potential to dramatically alter the performance of larval mosquitoes by altering either food resources or toxin concentrations. For example, inputs of native versus invasive litters have been shown to be important in mediating the effects of density dependence on the invasive mosquito A. albopictus in container systems [35]. Further, also in container habitats, leaf detritus from two invasive shrubs was shown to alleviate density dependent competition and promote higher adult emergence of Culex pipiens (L.) than detritus from native species, and this outcome appeared to be related to differences in associated bacterial communities [12]. Fewer studies have examined the effects of detritus type on larval mosquito performance in ground pool habitats, but at least one study has shown that the mowing of invasive Phragmites australis and Typha spp. around the perimeters of stormwater detention ditches dramatically increased abundances of larval mosquitoes in the ditches and adults infected with West Nile virus (WNV) in adjacent resident areas [36].

C. pipiens invaded the northern United States from Europe in the 16-17th centuries and has since established a wide geographical distribution across temperate regions in the country $[37,38]$. C. pipiens has spread into numerous other regions worldwide to now be distributed circumglobally [39]. Despite being generally well described in its established regions, C. pipiens continues to invade new areas [40]. C. pipiens obtains its blood meals primarily from birds but also opportunistically bites humans [41]. The species is a vector of St. Louis Encephalitis virus and WNV; thus, impacts on its distribution and abundance via interactions with other invasive species is of human health importance [42-44]. C. pipiens regularly inhabit highly ephemeral containers and ground pools, the latter of which include stormwater ponds, ditches, and wetland perimeters. These systems are small, discrete, and shaded habitats that usually lack vertebrate (e.g., fish, frogs) and invertebrate (e.g., beetles, damselflies) predators $[5,9,45]$. Such pools often persist for long enough periods of time to allow for the production of adult mosquitoes and can represent an important source of biting adults $[5,46]$. Detritus from plant species around the perimeter of these habitats is likely to affect the development of C. pipiens larvae and the production and fitness of biting adults, thereby influencing their regional abundance and disease transmission risk.

Common plant species that colonize ephemeral ground pools include both native species, such as Juncus effusus L., (soft rush) and Typha latifolia L. (broad-leaved cattail), and exotic invasive species Phragmites australis, (common reed) and Schedonorus arundinaceus (Schreb.) Dumort. (tall fescue). J. effusus is a slow spreading grass-like perennial that spreads primarily through seed dispersal, but can also spread vegetatively [47]. It is tolerant of diverse site conditions, including fresh waters and seasonal wetlands, and thrives in shallow waters [47]. T. latifolia is a perennial of the cattail family 
that has the ability to clone rapidly and spread by seed. This species is tolerant of fresh and brackish conditions and water level fluctuations [48]. P. australis is a species that historically could not be easily classified as native or introduced in North America due to a sudden increase in its spread on the continent. This spread, however, was shown to be due an invasive Eurasian genotype that had been introduced in the early part of the 19th century [49]. P. australis is a perennial reed that can spread rapidly by vegetative reproduction in addition to the production of seeds. It has a large biomass, enabling it to out-compete resident plant species through interference and exploitative competition [50-52]. The species is abundant in freshwater and brackish marsh habitats and has become increasingly common in disturbed sites, such as stormwater structures [49]. An introduced plant that is well adapted to disturbed areas, S. arundinaceus is a long-lived, deep-rooted, and perennial bunchgrass native to Europe [53]. This grass spreads most effectively through seeding but may also have short and slowly spreading rhizomes. It is common in damp grasslands and along riverbanks, has been planted as a forage grass as well as a means of erosion control and phytoremediation, and is regularly managed around stormwater structures and other ground depressions [53].

We examined the potential of invasive P. australis and S. arundinaceus and native T. latifolia and J. effusus at affecting performance of larval C. pipiens in ephemeral ground pool systems. We conducted a field survey of stormwater roadside ditches to identify the density and diversity of mosquito larvae in habitats that received detritus inputs of either of these four focal species. We also conducted a laboratory microcosm experiment assessing the water quality of systems containing different detritus inputs and the subsequent population performance of C. pipiens in those systems. Field observations indicated that detritus from P. australis, T. latifolia, and J. effusus were entirely from senescent litter while that of $S$. arundinaceus was always fresh clippings from regular mowing. We hypothesized that detritus type altered the population performance of $C$. pipiens by affecting food availability or habitat toxicity. Based on our hypothesis we predicted that, in the field, variation in mosquito densities among roadside stormwater ditches would be related their dominant vegetation and, in the laboratory experiment, detritus type would differentially affect density dependent competition of mosquito larvae or density independent toxicity.

\section{Materials and Methods}

\subsection{Field Survey}

Mosquitoes and plant detritus was sampled from 16 roadside stormwater ditches in the Watts Branch watershed (lat. $39.225^{\circ}$, long. $76.867^{\circ}$ ), Maryland and Washington DC (USA) in August 2014. Watts Branch is a predominantly suburban tributary of the Anacostia River and is located approximately $160 \mathrm{~km}$ upstream of the Chesapeake Bay. Ditches were grouped by the dominant plant $(>90 \%)$ that bordered their edge and gave allochthonous detritus input, with S. arundinaceus, J. effusus, P. australis, and T. latifolia representing four ditches each. No collected mosquitoes are from endangered species and all collection sites were on publicly accessible lands; thus, no field permits were required to collect them. Based on prior observations earlier in the summer, each ditch was known to retain small ephemeral pools of water, contain detritus, and hold larval mosquitoes, so that they collectively represented stormwater structures that would likely produce pestiferous and vector adults. Ditches with P. australis, T. latifolia, and J. effusus regularly received senesced leaf litter, with litter mainly accumulating around their perimeter. Ditches with S. arundinaceus received pulses of fresh clippings when they were maintained by local public works departments; thus, we surveyed these ditches 1-2 days after a mowing event to capture these additions. All ditches were at least $750 \mathrm{~m}$ apart to maintain spatial independence and none had been sprayed with herbicides or mosquitocides during 2014. Within each ditch, sampling was focused on a single randomly selected pool. Pools ranged in size but were no larger than $1.4 \mathrm{~m}^{2}$ and $399 \mathrm{~L}$ so that we could realistically collect their entire detritus contents (Table 1), and their size did not vary between detritus types (Area: $\mathrm{F}_{3,13}=0.9501, p=0.4530$; Volume: $\left.\mathrm{F}_{3,13}=1.10, p=0.3953\right)$. 
From each ditch, mosquitoes were sampled by taking 10 dips with a standard $400 \mathrm{~mL}$ dipper around its perimeter to extract a total of $4 \mathrm{~L}$ water. A total of 24 pupae were collected in these samples, which were allowed to emerge into adults and identified to species level upon return to the laboratory. Eighteen adults were $C$. pipiens females, which were dried $\left(45^{\circ} \mathrm{C},>48 \mathrm{hrs}\right)$ and had their wing lengths measured as a reliable indicator of their body size. The remaining six adults were Aedes vexans. All larvae were stored in ethanol on return to the laboratory, and later enumerated and identified to species. Total plant litter was collected with a $150 \mu \mathrm{m} \mathrm{10"} \mathrm{D-net} \mathrm{and} \mathrm{by} \mathrm{hand.} \mathrm{All} \mathrm{pools} \mathrm{included}$ litter that was within the water ('wet' litter), which presumably supplied immediate resources to the aquatic environment, and litter piled on top of the water surface or at the immediate edge of the water that would likely provision the aquatic environment over time. We collected, dried $\left(60^{\circ} \mathrm{C}\right.$, $>72 \mathrm{hrs}$ ), and weighed both litter types to estimate total standing litter per area $\left(\mathrm{m}^{2}\right)$ and volume (L) and total wet standing litter per volume $(\mathrm{L})$ for each pool. Mosquitoes were regularly collected in D-nets, but were not retained for enumeration because D-net sweeps were difficult to standardize in the ditches, separating mosquitoes from detritus was difficult, and the majority of specimens were highly damaged by preventing reliable identification. Litter from P. australis, T. latifolia, and J. effusus ditches almost entirely consisted of senesced litter and represents normal plant material available to mosquitoes during their summer developmental period. Litter from S. arundinaceus ditches was unidentifiable to species but we assumed it was from mowed S. arundinaceus from in and around the ditch. Litter samples from one S. arundinaceus and one J. effusus ditch were improperly collected and dried; therefore, these study ditches were removed from our analyses to give 14 total study sites (File S1).

\subsection{Experimental Litter and Mosquitoes}

We collected senesced leaf litter of P. australis, T. latifolia, and J. effusus, and fresh clippings of $S$. arundinaceus from three sites on the University of Maryland campus, College Park, Maryland (USA) that were known to be free from any herbicide or mosquitocide applications. We dried all detritus $\left(60^{\circ} \mathrm{C},>72 \mathrm{hrs}\right)$ and assessed its carbon:nitrogen (C:N) ratio by randomly selecting five leaves and using a LECO CHN-2000 instrument (Leco Corporation, MI). The remaining detritus was cut into $\sim 3 \mathrm{~cm}$ strips. All mosquitoes used in this study were $\mathrm{F}_{1}-\mathrm{F}_{2}$ larvae derived from C. pipiens colonies that had been established from larvae collected from ephemeral ground pools in College Park, Maryland. Larvae were raised to adulthood on lacalbumin (MP Biomedicals LLC, Solon, OH, USA) and adult females were blood-fed on anesthetized mice to produce eggs. Eggs were hatched in lacalbumin solution and then rinsed within $24 \mathrm{hrs}$ of use. Anesthetization of mice was done under University of Maryland IACUC Protocol \#R-09-10.

\subsection{Laboratory Experiment}

The experiment consisted of sixteen treatments. Each treatment contained one of the four detritus types, as follows: S. arundinaceus, P. australis, T. latifolia, and J. effusus and one of four (10, 20, 30, and 40) C. pipiens densities. There were seven replicates of each detritus type at the 10 density level, six replicates at the 20 density level, and three replicates at the 30 and 40 C. pipiens densities to yield 76 total experimental units. Experimental units consisted of $400 \mathrm{ml}$ tri-pour cups with $360 \mathrm{ml}$ of DI water and provisioned with $1.0 \pm 0.01 \mathrm{~g}$ of detritus and $100 \mu \mathrm{L}$ microbial inoculate of water from a stormwater ditch. The amount of detritus per $\mathrm{L}$, mosquito density per $\mathrm{L}$, and mosquito density per g detritus were all within the range of conditions observed in roadside stormwater ditches (Table 1). Cups were randomized and placed in an environmental chamber at $26^{\circ} \mathrm{C}$ with a $14: 10$ (L:D) photoperiod. Due to egg availability, cups were entered into the experiment on four dates (blocks). For each cup, $<24 \mathrm{hr}$ old C. pipiens larvae were added after five days of being added into the chamber (experimental day 0 ). Cups were supplemented with $1.0 \pm 0.01 \mathrm{~g}$ of detritus on day 20 to mimic regular food addition in field ditches and DI water was added when needed to maintain $360 \mathrm{ml}$. Pupae were removed daily 
and placed in individual vials to eclose. Adult sex and eclosion day were recorded. Dry mass and wing length was measured for each female.

For each cup, the proportion of female survival to adulthood, the mean female mass, and the mean female development time were calculated. These fitness measures were used to estimate per capita rate of population change $\left(\lambda^{\prime}\right)[54]$, as follows:

$$
\lambda^{\prime}=\exp \left[\frac{\ln \left[\left(1 / N_{0}\right) \sum_{x} A_{x} f\left(w_{x}\right)\right]}{D+\left[\frac{\sum_{x} x A_{x} f\left(w_{x}\right)}{\sum_{x} A_{x} f\left(w_{x}\right)}\right]}\right]
$$

where $N_{0}$ is the initial number of females in the cohort (assumed to be $50 \%$ ), $A_{x}$ is the number of females eclosing on day $x, w_{x}$ is the mean body size of females eclosing on day $x, f\left(w_{x}\right)$ is a function relating to fecundity to body size, and $D$ is the time from adult ecolosion to reproduction, assumed to be 10 days for C. pipiens [38] (File S2). There is limited information on the fecundity to female body size relationship for $C$. pipiens. Almost all the information on this function is of an ecological biotype of C. pipiens, C. pipiens form molestus Forskal. C. pipiens f. molestus has a number of behavioral and physicological differences from C. pipiens, including the almost exclusive use of subterranean larval habitats and the ability to produce eggs without a vertebrate bloodmeal (autogeny) $[38,55,56]$. Egg rafts from autogenous species tend to have fewer eggs than those of anautogenous species (egg production requiring a bloodmeal), thus using a size-fecundity relationship based on C. pipiens $\mathrm{f}$. molestus is undesirable for C. pipiens that would inhabit an above-ground stormwater ditch [38]. Therefore, we developed a size-fecundity relationship for C. pipiens by rearing larvae from the colony and rearing them to adulthood. As adults eclosed they were placed in $20 \mathrm{~L}$ nylon screen cages and within 5-10 days were fed to repletion from an anaesthetized mouse, then isolated in $600 \mathrm{~mL}$ containers with a $40 \mathrm{~mL}$ cup of water. Egg rafts were allowed to hatch and in $<1$ day larvae were counted. After oviposition, all females were killed, dissected, and the numbers of mature eggs (stages 4 and 5; [57]) in their ovaries were counted. Fecundity was calculated by adding laid and unlaid mature eggs. Wings of all females were removed and measured. A total of 55 females entered the experiment. Killing and dissecting females after the first gonotrophic cycle is consistent with most prior studies that have examined the fecundity of mosquitoes (e.g., [21]) (File S2).

We measured detritus decay, microbial activity, and tannin-lignin concetration from a separate set of ninety-six cups without mosquitoes. Twenty-four cups were provisioned with $1.0 \pm 0.01 \mathrm{~g}$ of one the four litter species and $100 \mu \mathrm{L}$ microbial inoculate of pond water. Containers were randomized and placed in the environmental chamber. On experimental days 5, 9, 12, and 26, we destructively sampled six cups of each plant treatment. Cups were homogenized, and one $10 \mathrm{ml}$ sample was extracted to test for tannin-lignins (mg/L) using a Hach spectrophotometer and its Hach tannin-lignin test kit (Hach, Loveland, CO, USA). A $1 \mathrm{~mL}$ sample was also extracted from five of the six cups containing each of the detritus types (80 total) to test microbial energy output ( $\mu \mathrm{watts} / \mathrm{ml}$ ), which is a measure of microbial activity, using a 4100 Multi-Cell Differential Scanning Calorimeter (Calorimetry Sciences Corp., Lindon, UT, USA). Readings were recorded after a 60 min equilibration period at $26{ }^{\circ} \mathrm{C}$ using sterile techniques and following procedures of past studies [58-60]. After water samples were taken, all detritus was removed from each cup using a $100-\mu \mathrm{m}$ sieve, dried $\left(60^{\circ} \mathrm{C},>72 \mathrm{hrs}\right)$, and had their mass recorded to calculate percentage mass remaining (File S2).

\subsection{Statistical Analyses}

We tested the effect of plant species on both total standing litter per habitat area and volume, wet litter per volume, total mosquito density, total mosquitoes per wet litter from study ditches, and adult female body size using linear models (PROC GLM, [61]) Each response variable was $\log _{10}$ transformed ( +1 for microbial energy output) to meet assumptions of normality and homogeneity. 
Since we only had 18 adult females from all ditches, we pooled individuals from ditches within each dominant plant species. We analyzed $\lambda^{\prime}$ and its constituent fitness variables (proportion female survivorship, mean female mass, mean female development time), C:N ratio, and water quality variables (detritus decay rate, microbial production, and tannin-lignin) using linear models (PROC GLM, [61]). Numbers of C. pipiens and day were continuous variables, and detritus species and experiment entry date (block) were class variables in their respective models. We tested among detritus species for the quality of slopes of $\lambda^{\prime}$ and each fitness parameter versus numbers of $C$. pipiens and water quality variables versus day. If detritus species altered the density dependent competition for food or temporal water conditions, we expected that slopes would differ among detritus types, yielding significant $C$. pipiens density $\times$ detritus species or day $\times$ detritus species interactions. Survivorship was arcsine square-root +0.5 transformed, and microbial energy output, detritus mass, and tannin-lignin concentration were each $\log _{10}$ transformed ( +1 for microbial energy output) to meet assumptions of normality and homogeneity of variances. The value $\lambda^{\prime}$ did not meet the assumption of normality or homogeneity of variances despite transformations; thus, we tested for effects using a randomization test [62]. Since we ran models for multiple dependent variables on the same experimental units, we used a sequential Bonferroni adjustment for tests within each statistical model, with experimentwise $\alpha=0.05$. We tested for significant differences among detritus types using pairwise contrasts, with Tukey-Kramer adjustment for all possible comparisons within each analysis.

\section{Results}

\subsection{Field Survey}

We sampled a total of 835 larval mosquitoes from the 14 study ditches. C. pipiens was the most common species, constituting $69.9 \%$ (584) of all specimens, and found in all 14 ditches. A. vexans $(22.6 \%$, 189), Culex restuans $(4.2 \%, 35)$, Culex territans $(2.6 \%, 22)$, and Aedes japonicus $(<1.0 \%, 5)$ represented the other mosquito species that were collected. Standing litter varied considerably among ditches (Table 1 ). There was a significant effect of plant species on total litter per area $\left(\mathrm{df}_{3,10}, \mathrm{~F}=12.72, p=0.0009\right)$ and volume $\left(\mathrm{df}_{3,10}, \mathrm{~F}=8.59, p=0.0040\right)$, although post-hoc pairwise tests only detected differences among individual plant species for litter per area, with J. effusus ditches having lower litter than all other plant species ( $p$-values $=0.0007-0.0136$; other $p$-values $=0.3213-0.9455)$. There were no differences in wet litter per volume $\left(\mathrm{df}_{3,10}, \mathrm{~F}=2.61, p=0.1097\right)$, mosquito density $\left(\mathrm{df}_{3,10}, \mathrm{~F}=1.43, p=0.2925\right)$, or mosquito abundance per detritus amount $\left(\mathrm{df}_{3,10}, \mathrm{~F}=0.91, p=0.4696\right)$. There was a significant effect of plant species on the adult body size of females that had been collected as pupae $\left(\mathrm{n}=18, \mathrm{df}_{3,14}\right.$, $\mathrm{F}=31.35, p<0.0001$ ), with females being larger from ditches containing $S$. arundinaceus ( $p$-values $<$ $0.0001-0.0044)$ and smallest from ditches containing J. effusus ( $p$-values $<0.0001-0.0012$ ), compared with all other plant species. There was no difference in the mean size of females from ditches containing P. australis and T. latifolia $(p=0.8310)$.

Table 1. Mean \pm SE (range in parentheses) litter and mosquito parameters in roadside ditches with either S. arundinaceus, P. australis, T. latifolia, or J. effusus as the dominant emergent plant species. All litter was dried before weighing.

\begin{tabular}{|c|c|c|c|c|c|c|c|c|}
\hline Plant Species & $\begin{array}{l}\text { Number } \\
\text { of Sites }\end{array}$ & Area $\left(m^{2}\right)$ & $\begin{array}{c}\text { Litter Per } \\
\text { Area }\left(\mathrm{g} / \mathrm{m}^{2}\right)\end{array}$ & $\begin{array}{l}\text { Estimated } \\
\text { Volume (L) }\end{array}$ & $\begin{array}{l}\text { Total Litter } \\
\text { Per Volume } \\
\text { (g/L) }\end{array}$ & $\begin{array}{l}\text { Wet Litter Per } \\
\text { Volume (g/L) }\end{array}$ & $\begin{array}{c}\text { Mosquitoes/ } \\
\text { Volume } \\
\text { (no./L) }\end{array}$ & $\begin{array}{l}\text { Mosquitoes/Wet } \\
\text { Litter (no./g) }\end{array}$ \\
\hline S. arundinaceus & 3 & $\begin{array}{l}0.56 \pm 0.12 \\
(0.40-0.80)\end{array}$ & $\begin{array}{l}556.1 \pm 198.6 \\
(236.3-920.0)\end{array}$ & $\begin{array}{c}169.3 \pm 34.3 \\
(104.0-220.0)\end{array}$ & $\begin{array}{l}1.91 \pm 0.82 \\
(1.02-3.54)\end{array}$ & $\begin{array}{l}1.63 \pm 0.84 \\
(0.66-3.31)\end{array}$ & $\begin{array}{l}10.7 \pm 4.1 \\
(4.0-18.0)\end{array}$ & $\begin{array}{c}7.5 \pm 1.8 \\
(5.43-11.00)\end{array}$ \\
\hline P. australis & 4 & $\begin{array}{l}0.95 \pm 0.20 \\
(0.40-1.40)\end{array}$ & $\begin{array}{c}846.3 \pm 73.1 \\
(659.3-999.0)\end{array}$ & $\begin{array}{c}279.0 \pm 54.7 \\
(148.0-378.0)\end{array}$ & $\begin{array}{l}2.88 \pm 0.49 \\
(2.26-4.34)\end{array}$ & $\begin{array}{l}1.19 \pm 0.21 \\
(0.74-1.61)\end{array}$ & $\begin{array}{l}22.3 \pm 5.9 \\
(7.0-33.3)\end{array}$ & $\begin{array}{l}18.5 \pm 3.9 \\
(7.4-25.8)\end{array}$ \\
\hline T. latifolia & 4 & $\begin{array}{l}0.66 \pm 0.22 \\
(0.32-1.30)\end{array}$ & $\begin{array}{l}602.5 \pm 109.1 \\
(320.0-830.0)\end{array}$ & $\begin{array}{l}206.9 \pm 69.6 \\
(92.0-390.0)\end{array}$ & $\begin{array}{l}2.05 \pm 0.56 \\
(1.07-3.61)\end{array}$ & $\begin{array}{l}1.40 \pm 0.55 \\
(0.47-3.00)\end{array}$ & $\begin{array}{l}15.3 \pm 3.2 \\
(8.0-22.0)\end{array}$ & $\begin{array}{l}19.1 \pm 8.3 \\
(2.7-40.7)\end{array}$ \\
\hline J. effusus & 3 & $\begin{array}{l}0.56 \pm 0.12 \\
(0.40-0.80)\end{array}$ & $\begin{array}{c}136.9 \pm 12.5 \\
(123.8-162.0)\end{array}$ & $\begin{array}{c}151.3 \pm 23.1 \\
(112.0-192.0)\end{array}$ & $\begin{array}{l}0.50 \pm 0.02 \\
(0.45-0.54)\end{array}$ & $\begin{array}{l}0.39 \pm 0.01 \\
(0.37-0.40)\end{array}$ & $\begin{array}{c}8.8 \pm 2.9 \\
(3.0-12.5)\end{array}$ & $\begin{array}{l}22.1 \pm 7.2 \\
(8.0-31.6)\end{array}$ \\
\hline Total & 14 & $\begin{array}{l}0.70 \pm 0.10 \\
(0.32-1.40)\end{array}$ & $\begin{array}{c}562.4 \pm 85.1 \\
(123.8-999.0)\end{array}$ & $\begin{array}{l}207.5 \pm 27.6 \\
(92.0-390.0)\end{array}$ & $\begin{array}{l}1.92 \pm 0.33 \\
(0.45-4.34)\end{array}$ & $\begin{array}{l}1.18 \pm 0.25 \\
(0.37-3.31)\end{array}$ & $\begin{array}{c}14.9 \pm 2.40 \\
(3.0-33.3)\end{array}$ & $\begin{array}{c}17.1 \pm 3.1 \\
(2.70-40.7)\end{array}$ \\
\hline
\end{tabular}




\subsection{Laboratory Experiment}

The size-fecundity relationship we developed for Culex pipiens showed a significant positive relationship between female wing length and the number of eggs a female produced $\left(r^{2}=0.3724\right.$, $\mathrm{n}=55 ; \mathrm{F}_{1,53}=31.45, p=0.0001$; Figure 1). Thus, we were able to use the size-fecundity relationship as the variable $f\left(w_{x}\right)$ in $\lambda^{\prime}\left(f(w x)=0.5\left(148.05\left(w_{x}\right)-383.83\right)\right)$. Detritus litter, larval density, and their interaction did not affect $C$. pipiens $\lambda^{\prime}$ but did affect individual fitness parameters (Table 2). C. pipiens survivorship was negatively affected by density and differed significantly among detritus species (Table 2). Survivorship in cups containing S. arundinaceus was significantly lower than in cups containing other detritus species ( $p$-values $=0.0001-0.0100$, Figure 2A). Female development time was longer in cups with higher larval densities but a significant density by detritus species interaction indicates that the density effect was moderated by detritus species (Table 2). Density significantly increased development time in cups with T. latifolia, P. australis, and J. effusus ( $p$-values $<0.0001$ ), but had no effect in cups with $S$. arundinaceus $(p=0.4228$ ) (Figure 2B). Female mass significantly differed among detritus species (Table 2), being significantly greater in cups containing $S$. arundinaceus than in cups containing other detritus species ( $p$-values $<0.0001)$ and significantly less in cups containing J. effusus than in other detritus species ( $p$-values $<0.0001-0.0014$ ) (Figure 2C).

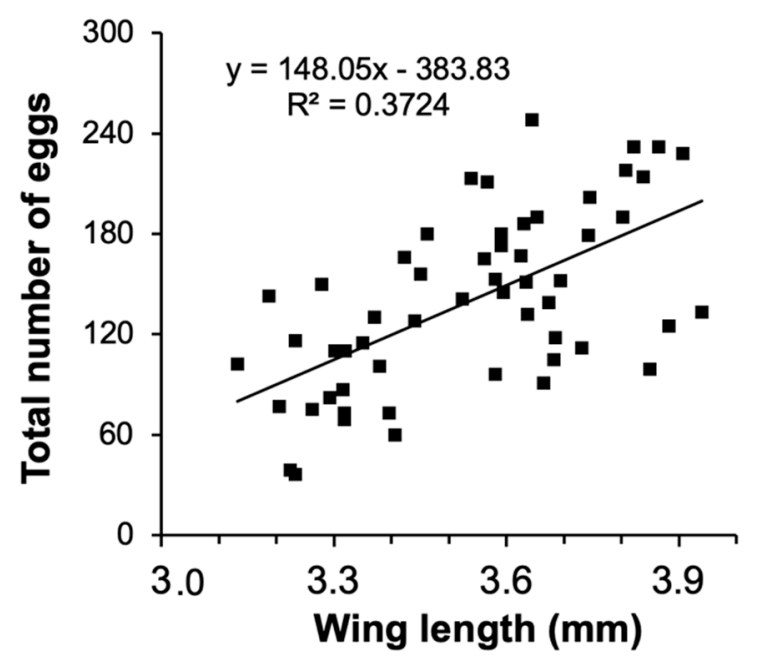

Figure 1. Relationship between number of eggs and wing length for C. pipiens.

Table 2. Results of randomization tests for $\lambda^{\prime}$, and linear models for female survivorship (arcsine square-root transformed), mean female mass, and mean female development time for C. pipiens. Effects significant at experimentwise $\alpha=0.05$ (sequential Bonferroni) are shown in bold. Models included block ( df = 3).

\begin{tabular}{ccccccccccc}
\hline \multirow{2}{*}{ Variable } & $\lambda^{\prime}$ & \multicolumn{3}{c}{ Survivorship } & \multicolumn{3}{c}{ Mass } & \multicolumn{3}{c}{ Development Time } \\
\cline { 2 - 11 } & Pr $>$ F & df & F Value & Pr $>$ F & df & F Value & Pr $>$ F & df & F Value & Pr $>$ F \\
\hline Detritus & 0.4190 & 3 & 1.43 & 0.2412 & 3 & 17.05 & $<\mathbf{0 . 0 0 0 1}$ & 3 & 1.94 & 0.1332 \\
Density & 0.2330 & 1 & 13.06 & $\mathbf{0 . 0 0 0 6}$ & 1 & 2.40 & 0.1270 & 1 & 69.88 & $<\mathbf{0 . 0 0 0 1}$ \\
Density $\mathbf{x}$ & 0.2310 & 3 & 0.30 & 0.8256 & 3 & 1.54 & 0.2137 & 3 & 8.98 & $<\mathbf{0 . 0 0 0 1}$ \\
Detritus & & & & 58 & & & 58 & & \\
Error & & 65 & & & & & & & &
\end{tabular}



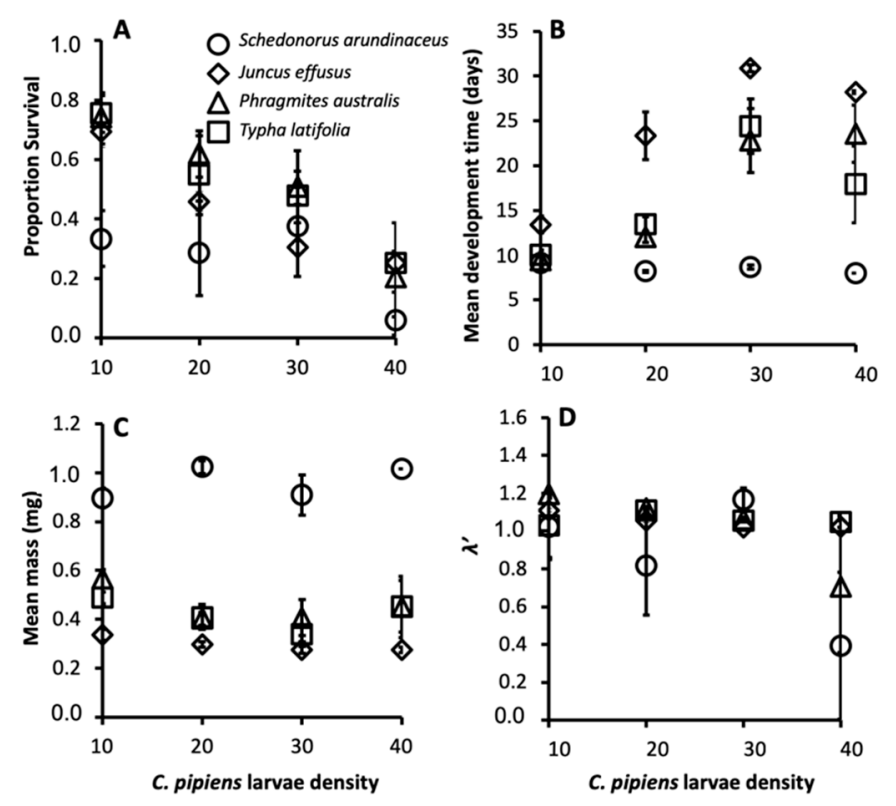

Figure 2. Mean female survivorship (A), female development time (B), female mass (C), and $\lambda^{\prime}$ (D) for C. pipiens provisioned with each detritus species. Error bars are \pm Standard Error of the Mean (SEM).

There were also significant differences in leaf chemistry and water quality among different detritus species. The C:N ratio varied among different detritus species $\left(\mathrm{F}_{3,16}=253.35, p<0.0001\right)$, with J. effusus and T. latifolia having the highest $\mathrm{C}: \mathrm{N}$ ratios, followed by $P$. australis then $S$. arundinaceus with the lowest (Figure 3). Decay rate varied among detritus species, as indicated by a significant detritus by day interaction (Table 3). S. arundinaceus decayed much faster and ended the experiment with less \% mass remaining compared to all other detritus species ( $p$-values $<0.0001)$ whose decay rates did not vary among themselves ( $p$-values $>0.10$ ) (Figure 4A). Likewise, microbial activity was consistently higher in cups with S. arundinaceus than those with other detritus species over the duration of the experiment and declined at a faster rate than J. effusus (Figure 4B, Table 3). Tannin-lignin varied significantly by detritus species (Table 3), with concentrations being significantly greater in cups containing S. arundinaceus than all other detritus species and greater in cups containing T. latifolia than those containing J. effusus $(p=0.0001)$ and P. australis $(p=0.0080)$ (Figure 4C).

Table 3. Results from linear models for detritus decay rate, microbial activity ( $\mu$ watts/mL), and tannin-lignin concentration $(\mathrm{mg} / \mathrm{L})\left(\right.$ all $\log _{10}$ transformed). Effects significant at experimentwise $\alpha=$ 0.05 (sequential Bonferroni) are shown in bold.

\begin{tabular}{cccccccccc}
\hline \multirow{2}{*}{ Variable } & \multicolumn{3}{c}{ Detritus decay } & \multicolumn{3}{c}{ Microbial Activity } & \multicolumn{3}{c}{ Tannin-Lignin } \\
\cline { 2 - 10 } & df & F Value & Pr $>$ F & df & F Value & Pr $>$ F & df & F Value & Pr $>$ F \\
\hline Detritus & 3 & 716.15 & $\mathbf{< . 0 0 0 1}$ & 3 & 41.31 & $<\mathbf{0 . 0 0 0 1}$ & 3 & 72.91 & $<\mathbf{0 . 0 0 0 1}$ \\
Day & 1 & 221.94 & $\mathbf{< 0 . 0 0 0 1}$ & 1 & 39.67 & $<0.0001$ & 1 & 1.68 & 0.1980 \\
Day x Detritus & 3 & 36.45 & $\mathbf{< . 0 0 0 1}$ & 3 & 3.90 & 0.0122 & 3 & 0.76 & 0.5213 \\
Error & 88 & & & 72 & & & 88 & & \\
\hline
\end{tabular}




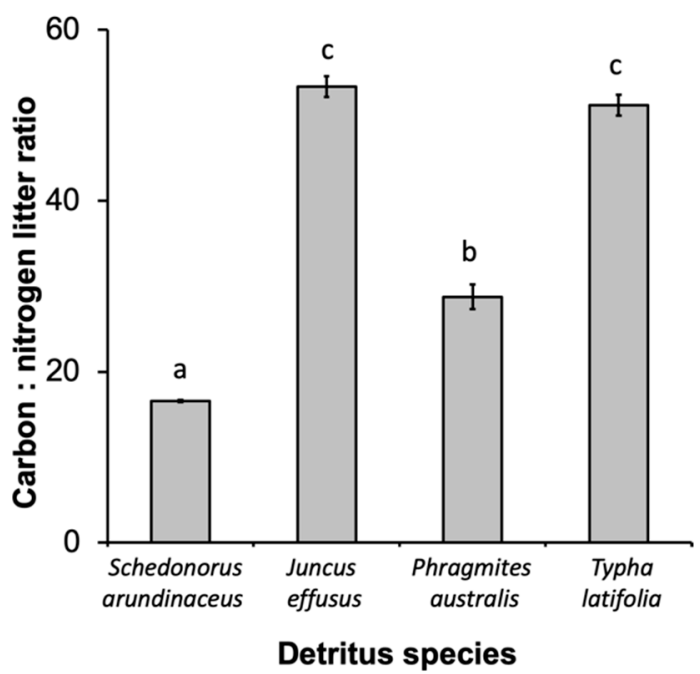

Figure 3. Carbon:nitrogen ratio for each detritus species. Different letters above bars denote statistically significant differences (experimentwise $\alpha=0.05$, sequential Bonferroni).
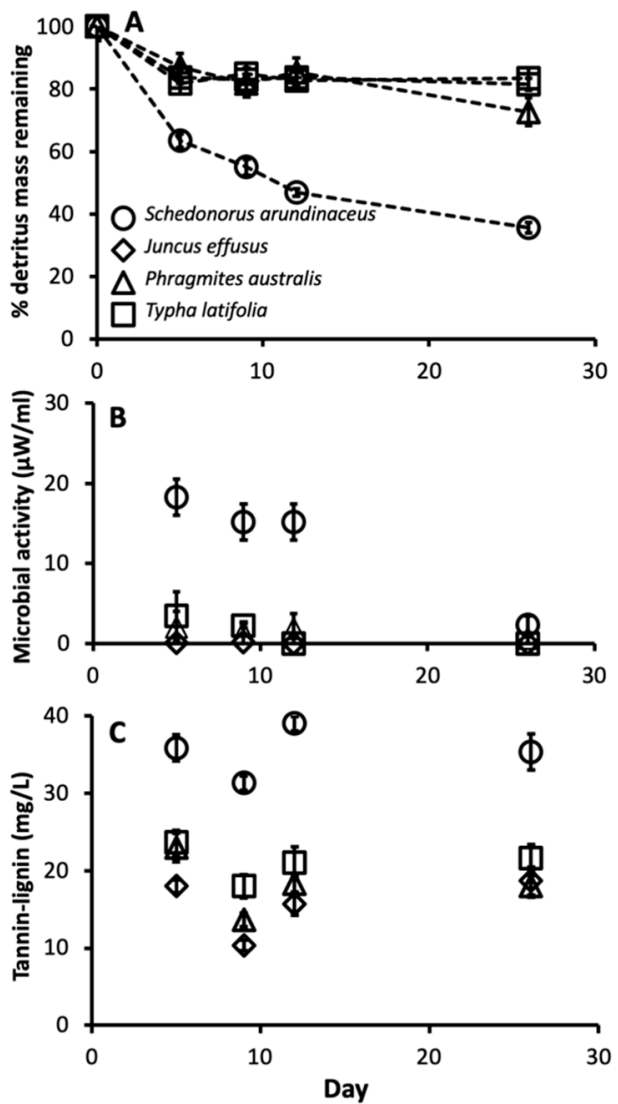

Figure 4. Mean microbial activity (A), \% detritus mass remaining (B), and tannin-lignin concentration (C) over time for cups provisioned with each detritus species. Error bars are \pm SEM.

\section{Discussion}

The co-occurrence of exotic species is becoming more common with the increasing spread of organisms worldwide, and a better understanding of their interactions is important to manage biological invasions. Invasive plants that alter the vegetation around ephemeral ground pools may facilitate or resist the spread of the exotic vector mosquito C. pipiens by altering allochthonous detritus inputs in 
those pools. In surveys of roadside stormwater ditches, mean C. pipiens densities did not differ among habitats that varied in litter species, but female $C$. pipiens were larger from ditches with $S$. arundinaceus and smaller with J. effusus compared to other plant species (P. australis and T. latifolia). In a laboratory microcosm experiment, $C$. pipiens per capita rate of population change $\left(\lambda^{\prime}\right)$ was unaffected when larvae were provisioned with different detritus species, yet larger adults emerged from microcosms with S. arundinaceus and smaller adults from microcosms with J. effusus. For adults of numerous mosquito species, larger size is related to survival [63-67], and adult survival has been shown to be a critical life-history parameter for pathogen transmission in mathematical models [29-31] and field studies [67]. The results of this study suggest that the invasion of $S$. arundinaceus in stormwater ditches or the displacement of J. effusus by P. australis invasion may alter disease transmission of C. pipiens by producing larger females. Body size is also related to fecundity in mosquitoes $[21,22,68,69]$. As a part of this study, we developed a fecundity to female body size relationship for C. pipiens based on data from the wing lengths of 55 females. This allowed us to calculate more accurate $\lambda^{\prime}$ estimates than past studies (e.g., $[17,70]$ ), which have used a function based on a relationship for four females from an autogenous form of $C$. pipiens that almost entirely uses subterranean environments, $C$. pipiens f. molestus $[38,55,56]$. Since egg rafts from autogenous mosquito species' tend to have fewer eggs than those of anautogenous species, using a size-fecundity relationship based on a small number of C. pipiens f. molestus is undesirable for above ground C. pipiens [38]. Therefore, we recommend future studies that require size-fecundity relationship for above-ground $C$. pipiens to refer to the function in this study until an even more robust size-fecundity relationship from a greater number of females over a wider range of wing lengths is calulcated.

Our findings suggest that the litter species within ephemeral ground pools could affect the risk of disease transmission from C. pipiens in urban areas. Although mosquito size is a consistent factor explaining variability in vector competence, there are conflicting data in the literature as to whether smaller or larger female mosquitoes are more competent disease vectors. Evidence for the efficacy of smaller mosquitoes in transmitting disease was noted in a study on A. albopictus and Aedes aegypti susceptibility to the Sindbis virus [24]. This study demonstrated that smaller mosquitoes from environments with high density-dependent competition had a higher body titer and higher likelihood of infection than larger mosquitoes from low competition environments. Conversely, other studies have demonstrated that larger females are more efficient disease vectors [21,71,72]. Xue et al. found that larger A. aegypti females live longer and are more likely to seek multiple blood feedings than smaller females, which increased the likelihood that they could become infected with a virus and transmit it to a host within their lifetime [71]. Juliano et al. used both laboratory experiments and field-collected female Ae. aegypti to demonstrate that intraspecific competition in larval habitats produced smaller females that had reduced survival and were less likely to be infected with dengue [67]. If larger C. pipiens females are more effective disease vectors, ephemeral pool systems with S. arundinaceus clippings would produce the most competent disease-transmitting mosquitoes, while pools with J. effusus detritus with would produce the least competent disease vectors. Changes in vegetation communities surrounding ephemeral pools could then alter the risk of disease transmission from mosquitoes based on which plant species were displaced. For example, if P. australis, which produces intermediate-sized females, displaced J. effusus the disease risk in the area could increase, while if P. australis displaced S. arundinaceus the risk could decrease. Alternatively, if larger C. pipiens females are less efficient vectors, scenarios conducive to the establishment of $S$. arundinaceus would result in a lower risk of disease transmission. Future research is needed to examine the susceptibility of arboviral infection specifically for C. pipiens females at different sizes and from different larval environments.

In this study, the effects of detritus species on C. pipiens performance in appear to be directly related to leaf chemistry and water quality. S. arundinaceus had the lowest $\mathrm{C}: \mathrm{N}$ ratio, the highest decay rate, and supported the greatest microbial activity. Larger adults that emerged from microcosms with $S$. arundinaceus were likely exposed to much greater microbial food, while the higher nutrient concentrations fouled the water, as indicated by a thick microbial film that coated the water surface 
(personal observation), presumably causing lethally toxic conditions for a proportion of the larvae. These results are consistent with previous laboratory and field studies of the effects of detritus species and resultant food resources on mosquito performance (e.g., $[10,11,15,73])$, including those that have demonstrated increased survival and abundances from fresh compared to senescent detritus [14,36]. S. arundinaceus also leached higher tannin-lignin concentrations than other detritus species, reaching a maximum of $40 \mathrm{mg} / \mathrm{L}$ over the study duration. It is possible that these concentrations may have had a negative effect on C. pipiens performance. Nevertheless, they are substantially lower than concentrations reported to cause negative effects on other mosquito species in prior studies (e.g., >100 mg/L, [73,74]), and further work be needed to tease apart the effects of tannins and fouling on $C$. pipiens from S. arundinaceus and other litter species in ground pool habitats. Larval density also proved to be an important factor in survival and development of $C$. pipiens. Habitats containing fewer mosquitoes produced larvae that developed faster and had a higher rate of survival to adulthood, likely due to less competition for food resources. Based on the results of this study, it is likely that both density dependent and density independent processes influence the growth and survival of mosquitoes in ephemeral stormwater drainage ditches.

The overall effects of plant litter on mosquitoes can be broadly divided into two main categories, as follows: The chemical characteristics of the litter (i.e., nutrient availability, toxins) and the overall productivity of the species. We focused on the chemical characteristics of litter in our laboratory experiment by controlling the amount of litter that we added to the microcosms, and found that microcosms provisioned with J. effusus produced smaller females because of a slower decay rate and lower resource availability. We also recovered less litter from ditches with J. effusus compared to the three other plant species, indicating that the unfavorable conditions of $J$. effusus litter is likely compounded by its lower productivity in the field. These findings are consistent with past studies that appear to show much greater production from P. australis and T. latifolia than J. effusus [75,76]. Robust estimates of clippings from mowing $S$. arundinaceus or any other grasses in field habitats are scant but likely to be highly variable based on local management. Past studies have shown that plant clippings deposited from mowing stormwater BMPs (Best Management Practices) are often left in situ [77]. Based on the findings in our study here, we might expect the deposition of $S$. arundinaceus clippings from mowing to cause pulses of larger $C$. pipiens adults that are better disease vectors. To minimize disease risks from C. pipiens, local jurisdictions should consider capturing clippings around stormwater ditches and other BMPs that might provide habitat for this and vector mosquito species.

Few studies have compared the effects of invasive versus native litter on C. pipiens population dynamics [12,78], and only one study that we are aware of has addressed the effects of litter detritus on C. pipiens in ground pools [36]. MacKay et al. found that stormwater dry detention basins that received fresh clippings of invasive Typha spp. and P. australis that had been mowed had higher abundances of mosquitoes, including C. pipiens, than before mowing and to basins that were never mowed [36]. The authors concluded that, in addition to nutrient enrichment and increased larval survival, this result was also partly due to increased oviposition, based on an associated oviposition experiment that manipulated detritus additions in experimental microcosms. In our study here, we did not observe any relationships between detritus species on $\lambda^{\prime}$ or survival in experimental microcosms in the laboratory or on densities in field ditches, suggesting that regional abundances of $C$. pipiens may be unaffected by the dominant detrital litter species. Body size is positively associated with mosquito fecundity [21,22,69], but greater egg production from larger females that have been raised on S. arundinaceus appear to be offset by decreases in larval survival, and likely explains why we observed no effects of litter species on abundances in field stormwater ditches. Nevertheless, we did not study oviposition rates in the field or experimentally test the effects of detritus species on C. pipiens oviposition and, therefore, its role on moderating relative abundances of the species among ditches surrounded by the plants in this study needs further study. Furthermore, P. australis and S. arundinaceus introductions could influence mosquito productivity through additional mechanisms other than altering resource availability, larval density, and fouling effects. Additional studies could 
examine the effect of $P$. australis and S. arundinaceus on nutrient removal from permanent stormwater BMPs, as well as interactions between detrital species, predation, and interspecific competition at the community level. Vegetation communities can also affect other aspects of adult mosquito ecology, such as resting sites, host habitat, or adult food sources; therefore, variability in the composition of local plant communities could indirectly affect oviposition in nearby ground pools by altering local adult abundances. Our field survey identified important relationships among plant species and C. pipiens in stormwater drainage ditches, but it was relatively limited in its scope, both with regards to space and time. Phenological differences among plant species (growth rates, nutrient sequestration, deposition of senescent litter) might alter the abundance and size of $C$. pipiens and other mosquito species developing in associated ground pool habitats. In particular, our conclusions on the effects of litter species on adult female body size and related pathogen transmission are based on only 18 individuals. Although we detected significant differences in adult size from ditches with different litter species, we only collected 2 females from ditches with J. effusus (6 from S. arundinaceus and T. latifolia, and 4 from P. australis). More extensive field and laboratory studies that test the effects of variable amounts and timing of detritus inputs on the performance of mosquito species among a wider range and greater number of sites would lead to a better understanding of vector ecology and associated transmission risks from stormwater BMPs.

\section{Conclusions}

This study suggests that disease risks from C. pipiens may increase if the clippings from mowing introduced S. arundinaceus grass around stormwater drainage ditches or other BMPs are left in situ or if invasive P. australis displaces native J. effusus. Higher transmission risks appear to result from increases in microbial food that lead to larger females that likely have a greater potential for transmitting arboviruses. Our study is among the first to demonstrate that shifting community-level interactions from plant invasions in an ephemeral ground pool system might affect the fitness of C. pipiens and increase risks from West Nile virus.

Supplementary Materials: The following are available online at http://www.mdpi.com/1660-4601/16/21/4118/s1, File S1: Field data, File S2: Lab data.

Author Contributions: Conceptualization, P.T.L., B.S., A.H.B., S.L.L.; methodology, P.T.L., B.S.; formal analysis, P.T.L., B.S.; writing—original draft preparation, P.T.L., B.S.; writing—review and editing, P.T.L., A.H.B., S.L.L.

Funding: This research was funded by U.S. Geological Survey MIWRRC, grant 2010MD206B and the NSF Coupled Natural Human Systems Program, grant 1824807.

Acknowledgments: The authors wish to thank Brandon Scott, Rachel Pozzatti, Durga Maheshwaran for assistance conducting the study, and Steven Juliano and Bahram Momen for statistical advice.

Conflicts of Interest: The authors declare no conflict of interest. The funders had no role in the design of the study; in the collection, analyses, or interpretation of data; in the writing of the manuscript, or in the decision to publish the results.

\section{References}

1. Simberloff, D.; Von Holle, B. Positive interactions of nonindigenous species: Invasional meltdown? Biol. Invasions 1999, 1, 21-32. [CrossRef]

2. Shea, K.; Chesson, P. Community ecology theory as a framework for biological invasions. Trends Ecol. Evol. 2002, 17, 170-176. [CrossRef]

3. Ehrenfeld, J.G. Ecosystem consequences of biological invasions. Annu. Rev. Ecol. Evol. Syst. 2010, 41, 59-80. [CrossRef]

4. Merritt, R.W.; Dadd, R.H.; Walker, E.D. Feeding-behavior, natural food, and nutritional relationships of larval mosquitoes. Annu. Rev. Entomol. 1992, 37, 349-376. [CrossRef] [PubMed]

5. Batzer, D.P.; Wissinger, S.A. Ecology of insect communities in nontidal wetlands. Annu. Rev. Entomol. 1996, 41, 75-100. [CrossRef] [PubMed] 
6. Juliano, S.A. Species interactions among larval mosquitoes: Context dependence across habitat gradients. Annu. Rev. Entomol. 2009, 54,37-56. [CrossRef]

7. Kuller, Z.; Gasith, A. Comparison of the hatching process of the tadpole shrimps Triops cancriformis and Lepidurus apus lubbocki (Notostraca) and its relation to their distribution in rain-pools in Israel. Hydrobiologia 1996, 335, 147-157. [CrossRef]

8. Wallace, J.R.; Merritt, R.W. Diel feeding periodicity of larval anopheline mosquitoes on microorganisms and microinvertebrates: A spatial and temporal comparison of Anopheles quadrimaculatus (Diptera: Culicidae) diets in a Michigan pond. J. Med. Entomol. 2004, 41, 853-860. [CrossRef]

9. Wellborn, G.A.; Skelly, D.K.; Werner, E.E. Mechanisms creating community structure across a freshwater habitat gradient. Annu. Rev. Ecol. Syst. 1996, 27, 337-363. [CrossRef]

10. Walker, E.D.; Lawson, D.L.; Merritt, R.W.; Morgan, W.T.; Klug, M.J. Nutrient dynamics, bacterial populations, and mosquito productivity in tree hole ecosystems and microcosms. Ecology 1991, 72, 1529-1546. [CrossRef]

11. Yee, D.A.; Juliano, S.A. Consequences of detritus type in an aquatic microsystem: Effects on water quality, micro-organisms and performance of the dominant consumer. Freshw. Biol. 2006, 51, 448-459. [CrossRef] [PubMed]

12. Gardner, A.M.; Allan, B.F.; Frisbie, L.A.; Muturi, E.J. Asymmetric effects of native and exotic invasive shrubs on ecology of the West Nile virus vector Culex pipiens (Diptera: Culicidae). Parasites Vectors 2015, 8, 329. [CrossRef] [PubMed]

13. Barrera, R. Competition and resistance to starvation in larvae of container-inhabiting Aedes mosquitoes. Ecol. Entomol. 1996, 21, 117-127. [CrossRef]

14. Murrell, E.G.; Juliano, S.A. Detritus type alters the outcome of interspecific competition between Aedes aegypti and Aedes albopictus (Diptera: Culicidae). J. Med. Entomol. 2008, 45, 375-383. [CrossRef]

15. Fish, D.; Carpenter, S.R. Leaf litter and larval mosquito dynamics in tree-hole ecosystems. Ecology 1982, 63, 283-288. [CrossRef]

16. Dieng, H.; Mwandawiro, C.; Boots, M.; Morales, R.; Satho, T.; Tuno, N.; Tsuda, Y.; Takagi, M. Leaf litter decay process and the growth performance of Aedes albopictus larvae (Diptera: Culicidae). J. Vector Ecol. 2002, 27, 31-38.

17. Costanzo, K.S.; Muturi, E.J.; Lampman, H.L.; Alto, B.W. The effects of resource type and ratio on competition with Aedes albopictus and Culex pipiens (Diptera: Culicidae). J. Med. Entomol. 2011, 48, 29-38. [CrossRef]

18. Daugherty, M.P.; Alto, B.W.; Juliano, S.A. Invertebrate carcasses as a resource for competing Aedes albopictus and Aedes aegypti (Diptera: Culicidae). J. Med. Entomol. 2000, 37, 364-372. [CrossRef]

19. Muturi, E.J.; Allan, B.F.; Ricci, J. Influence of leaf detritus type on production and longevity of container-breeding mosquitoes. Environ. Entomol. 2012, 41, 1062-1068. [CrossRef]

20. Blackmore, M.S.; Lord, C.C. The relationship between size and fecundity in Aedes albopictus. J. Vector Ecol. 2000, 35, 212-217.

21. Armbruster, P.; Hutchinson, R.A. Pupal mass and wing length as indicators of fecundity in Aedes albopictus and Aedes geniculatus (Diptera: Culicidae). J. Med. Entomol. 2002, 39, 699-704. [CrossRef] [PubMed]

22. Leisnham, P.T.; Lounibos, L.P.; O'Meara, G.F.; Juliano, S.A. Interpopulation divergence in competitive interactions of the mosquito Aedes albopictus. Ecology 2009, 90, 2405-2413. [CrossRef] [PubMed]

23. Leisnham, P.T.; Sala, L.M.; Juliano, S.A. Geographic variation in adult survival and reproduction of the mosquito Aedes albopictus. J. Med. Entomol. 2008, 45, 210-221. [CrossRef]

24. Alto, B.W.; Lounibos, L.P.; Higgs, S.; Juliano, S.A. Larval competition differentially affects arbovirus infection in Aedes mosquitoes. Ecology 2005, 86, 3279-3288. [CrossRef]

25. Alto, B.W.; Lounibos, L.P.; Mores, C.N.; Reiskind, M.H. Larval competition alters susceptibility of adult Aedes mosquitoes to dengue infection. Proc. R. Soc. B Biol. Sci. 2008, 275, 463-471. [CrossRef]

26. Zirbel, K.; Eastmond, B.; Alto, B.W. Parental and offspring larval diets interact to influence life-history traits and infection with dengue virus in Aedes aegypti. R. Soc. Open Sci. 2018, 5, 180539. [CrossRef]

27. Livdahl, T.P.; Sugihara, G. Non-linear interactions of populations and the importance of estimating per capita rates of change. J. Anim. Ecol. 1984, 53, 573-580. [CrossRef]

28. Costanzo, K.S.; Westby, K.M.; Medley, K.A. Genetic and environmental influences on the size-fecundity relationship in Aedes albopictus (Diptera: Culicidae): Impacts on population growth estimates? PLoS ONE 2018, 13, e0201465. [CrossRef] 
29. Smith, D.L.; Battle, K.E.; Hay, S.I.; Barker, C.M.; Scott, T.W.; McKenzie, F.E. Ross, macdonald, and a theory for the dynamics and control of mosquito-transmitted pathogens. PLoS Pathog. 2012, 8, e1002588. [CrossRef]

30. Hawley, W.A. The effect of larval density on adult longevity of a mosquito, Aedes sierrentis: Epidemiological consequences. J. Anim. Ecol. 1985, 54, 955-964. [CrossRef]

31. LaDeau, S.L.; Allan, B.F.; Leisnham, P.T.; Levy, M.Z. The ecological foundations of transmission potential and vector-borne disease in urban landscapes. Funct. Ecol. 2015, 29, 889-901. [CrossRef] [PubMed]

32. Ukubuiwe, A.C.; Ojianwuna, C.C.; Olayemi, I.K.; Arimoro, F.O.; Omalu, I.C.J.; Ukubuiwe, C.C.; Baba, B.M. Quantifying the influence of larval density on disease transmission indices in Culex quinquefasciatus, the major African vector of filariasis. Int. J. Insect Sci. 2019, 11, 1179543319856022. [CrossRef] [PubMed]

33. Sota, T.; Mogi, M. Interspecific variation in desiccation survival time of Aedes (Stegomyia) mosquito eggs is correlated with habitat and egg size. Oecologia 1992, 90, 353-358. [CrossRef] [PubMed]

34. Mercer, D.R.; Anderson, J.R. Tannins in treehole habitats and their effects on Aedes sierrensis (Diptera: Culicidae) production and parasitism by Lambornella clarki (Ciliophera: Tetrahymenidae). J. Med. Entomol. 1994, 31, 159-167. [CrossRef]

35. Reiskind, M.H.; Greene, K.L.; Lounibos, L.P. Leaf species identity and combination affect performance and oviposition choice of two container mosquito species. Ecol. Entomol. 2009, 34, 447-456. [CrossRef]

36. Mackay, A.J.; Muturi, E.J.; Ward, M.P.; Allan, B.F. Cascade of ecological consequences for West Nile virus transmission when aquatic macrophytes invade stormwater habitats. Ecol. Appl. 2015, 26, 219-232. [CrossRef]

37. Kesavaraju, B.; Khan, D.F.; Gaugler, R. Behavioral differences of invasive container-dwelling mosquitoes to a native predator. J. Med. Entomol. 2011, 48, 526-532. [CrossRef]

38. Vinogradova, E.B. Culex Pipiens Pipiens Mosquitoes; Taxonomy, Distribution, Ecology, Physiology, Genetics, Applied Importance and Control; Pensoft: Sofia, Bulgaria, 2000.

39. Lounibos, L.P. Invasions by insect vectors of human disease. Annu. Rev. Entomol. 2002, 47, $233-266$. [CrossRef]

40. Chaulk, A.C.; Carson, K.P.; Whitney, H.G.; Fonseca, D.M.; Chapman, T.W. The Arrival of the northern house mosquito Culex pipiens (Diptera: Culicidae) on Newfoundland's Avalon Peninsula. J. Med. Entomol. 2016, 53, 1364-1369. [CrossRef]

41. Byrne, K.; Nichols, R.A. Culex pipiens in London Underground tunnels: Differentiation between surface and subterranean populations. Heredity 1999, 82, 7-15. [CrossRef]

42. Apperson, C.S.; Harrison, B.A.; Unnasch, T.R.; Hassan, H.K.; Irby, W.S.; Savage, H.M.; Aspen, S.E.; Watson, D.W.; Rueda, L.M.; Engber, B.R.; et al. Host-feeding habits of Culex and other mosquitoes (Diptera: Culicidae) in the Borough of Queens in New York City, with characters and techniques for identification of Culex mosquitoes. J. Med. Entomol. 2002, 39, 777-785. [CrossRef] [PubMed]

43. Lampman, R.L.; Krasavin, N.M.; Szyska, M.; Novak, R.J. A comparison of two West Nile virus detection assays (TaqMan reverse transcriptase polymerase chain reaction and VecTest antigen assay) during three consecutive outbreaks in northern Illinois. J. Am. Mosq. Control Assoc. 2006, 22, 76-86. [CrossRef]

44. Spielman, A.; Andreadis, T.G.; Apperson, C.S.; Cornel, A.J.; Day, J.F.; Edman, J.D.; Fish, D.; Harrington, L.C.; Kiszewski, A.E.; Lampman, R.; et al. Outbreak of West Nile virus in North America. Science 2004, 306, 1473-1475. [CrossRef] [PubMed]

45. Washburn, J.O. Regulatory factors affecting larval mosquito populations in container and pool babitats-Implications for biological control. J. Am. Mosq. Control Assoc. 1995, 11, 279-283. [PubMed]

46. Kwan, J.A.; Riggs-Nagy, J.M.; Fritz, C.L.; Shindelbower, M.; Castro, P.A.; Kramer, V.L.; Metzger, M.E. Mosquito production in stormwater treatment devices in the Lake Tahoe Basin, California. J. Am. Mosq. Control Assoc. 2008, 24, 82-89. [CrossRef]

47. Stevens, M. Sort Rush Juncus effusus L. Available online: https://plants.usda.gov/plantguide/pdf/cs_juef.pdf (accessed on 2 July 2019).

48. Stevens, M.; Hoag, C. Broad-Leafed Cattail Typha latifolia L. Available online: https://plants.usda.gov/ plantguide/pdf/cs_tyla.pdf (accessed on 12 September 2019).

49. Saltonstall, K. Cryptic invasion by a non-native genotype of the common reed, Phragmites australis, into North America. Proc. Natl. Acad. Sci. USA 2002, 99, 2445-2449. [CrossRef]

50. Burdick, D.M.; Buchsbaum, R.; Holt, E. Variation in soil salinity associated with expansion of Phragmites australis in salt marshes. Environ. Exp. Bot. 2001, 46, 247-261. [CrossRef] 
51. Howard, R.J.; Travis, S.E.; Sikes, B.A. Rapid growth of a Eurasian haplotype of Phragmites australis in a restored brackish marsh in Louisiana, USA. Biol. Invasions 2008, 10, 369-379. [CrossRef]

52. Magee, P. Common Reed: Phragmites australis (Cav.) Trin. ex Steud. Available online: http://plants.usda.gov/ factsheet/pdf/fs_phau7.pdf (accessed on 9 December 2019).

53. Henson, J.F. Tall Fescue: Lolium arundinaceum (Schreb.) S.J. Darbyshire. Available online: http://plants.usda. gov/plantguide/pdf/pg_loar10.pdf (accessed on 9 September 2019).

54. Juliano, S.A. Species introduction and replacement among mosquitoes: Interspecific resource competition or apparent competition? Ecology 1998, 79, 255-268. [CrossRef]

55. Mattingly, P.F. The problem of biological races in the Culex pipiens complex. Proc. Linn. Soc. Lond. 1952, 163, 53-57. [CrossRef]

56. Harbach, R.E.; Harrison, B.A.; Gad, A.M. Culex (Culex) molestus Forskal (Diptera, Culicidae): Neotype designation, description, variation, and taxonomic status. Proc. Entomol. Soc. Wash. 1984, 86, 521-542.

57. Detinova, T.S. Age-Grouping Methods in Diptera of Medical Importance; World Health Organization: Geneva, Switzerland, 1962; p. 216.

58. Zhang, H.; Liu, J.; Li, C.; Momen, B.; Kohanski, R.; Pick, L. Deletion of Drosophila insulin-like peptides causes growth defects and metabolic abnormalities. Proc. Natl. Acad. Sci. USA 2009, 106, 19617-19622. [CrossRef] [PubMed]

59. Braissant, O.; Wirz, D.; Gopfert, B.; Daniels, A. Use of isothermal microcalorimeter to monitor microbial activities. FEMS Microbiol. Lett. 2010, 303, 1-18. [CrossRef] [PubMed]

60. Villena, O.; Momen, B.; Sullivan, J.; Leisnham, P. Effects of ultraviolet radiation on metabolic rate and fitness of Aedes albopictus and Culex pipiens mosquitoes. PeerJ 2018, 6, e6133. [CrossRef]

61. SAS Institute Inc. SAS User's Guide: Statistics; Version 9.1; SAS Institute Inc.: Cary, NC, USA, 2003.

62. Cassell, D.L. A Randomization-Test Wrapper for SAS PROCs; SAS Institute Inc.: Cary, NC, USA, 2011.

63. Briegel, H.; Timmermann, S.E. Aedes albopictus (Diptera: Culicidae): Physiological aspects of development and reproduction. J. Med. Entomol. 2001, 38, 566-571. [CrossRef]

64. Ameneshewa, B.; Service, M.W. The relationship between female body size and survival rate of the malaria vector Anopheles arabiensis in Ethiopia. Med. Vet. Entomol. 1996, 10, 170-172. [CrossRef]

65. Alto, B.W.; Muturi, E.J.; Lampman, R.L. Effects of nutrition and density in Culex pipiens. Med. Vet. Entomol. 2012, 26, 396-406. [CrossRef]

66. Alto, B.W.; Bettinardi, D.J.; Ortiz, S. Interspecific larval competition differentially impacts adult survival in dengue vectors. J. Med. Entomol. 2015, 52, 163-170. [CrossRef]

67. Juliano, S.A.; Ribeiro, G.S.; Maciel-De-Freitas, R.; Castro, M.G.; Codeco, C.; Lourenco-de-Oliveira, R.; Lounibos, L.P. She's a femme fatale: Low-density larval development produces good disease vectors. Mem. Inst. Oswaldo Cruz 2014, 109, 1070-1077. [CrossRef]

68. Lounibos, L.P.; Suarez, S.; Menendez, Z.; Nishimura, N.; Escher, R.L.; SM, O.C.; Rey, J.R. Does temperature affect the outcome of larval competition between Aedes aegypti and Aedes albopictus? J. Vector Ecol. 2002, 27, 86-95.

69. Leisnham, P.T.; Juliano, S.A. Interpopulation differences in competitive effect and response of the mosquito Aedes aegypti and resistance to invasion by a superior competitor. Oecologia 2010, 164, 221-230. [CrossRef] [PubMed]

70. Costanzo, K.S.; Mormann, K.; Juliano, S.A. Asymmetrical competition and patterns of abundance of Aedes albopictus. J. Med. Entomol. 2005, 42. [CrossRef]

71. Xue, R.; Barnard, D.R.; Schreck, C.E. Influence of body size and age of Aedes albopictus on human host attack rates and the repellency of deet. J. Am. Mosq. Control Assoc. 1995, 11, 50-53. [PubMed]

72. Briegel, H. Physiological bases of mosquito ecology. J. Vector Ecol. 2003, 28, 1-11. [PubMed]

73. Smith, C.; Baldwin, A.H.; Sullivan, J.; Leisnham, P.T. Effects of elevated atmospheric $\mathrm{CO}_{2}$ on competition between the mosquitoes Aedes albopictus and Ae. triseriatus via changes in litter quality and production. J. Med. Entomol. 2013, 50, 521-532. [CrossRef]

74. Sota, T. Performance of Aedes albopictus and A. riversi larvae (Diptera: Culicidae) in waters that contain tannic acid and decaying leaves: Is the treehole species better adapted to treehole water? Ann. Entomol. Soc. Am. 1993, 86, 450-457. [CrossRef]

75. Christensen, J.R.; Crumpton, W.G.; Van der Valk, A.G. Estimating the breakdown and accumulation of emergent macrophyte litter: A mass-balance approach. Wetlands 2009, 29, 204-214. [CrossRef] 
76. Kuehn, K.A.; Suberkropp, K. Decomposition of standing litter of the freshwater emergent macrophyte Juncus effusus. Freshw. Biol. 1998, 40, 717-727. [CrossRef]

77. Schultz, D. Current Status of Vegetation Management in Roadside Ditches and Stormwater Management Facilities: Implications for Stormwater Quality; Center for Urban Water Resources Management, Department of Civil Engineering, University of Washington: Seattle, WA, USA, 1998; p. 30.

78. Shewhart, L.; McEwan, R.W.; Benbow, M.E. Evidence for facilitation of Culex pipiens (Diptera: Culicidae) life history traits by the nonnative invasive shrub Amur Honeysuckle (Lonicera maackii). Environ. Entomol. 2014, 43, 1584-1593. [CrossRef]

(C) 2019 by the authors. Licensee MDPI, Basel, Switzerland. This article is an open access article distributed under the terms and conditions of the Creative Commons Attribution (CC BY) license (http://creativecommons.org/licenses/by/4.0/). 